ENTREPRENEURSHIP AND SUSTAINABILITY ISSUES

ISSN 2345-0282 (online) http://jssidoi.org/jesi/

2020 Volume 7 Number 4 (June)

http://doi.org/10.9770/jesi.2020.7.4(34)

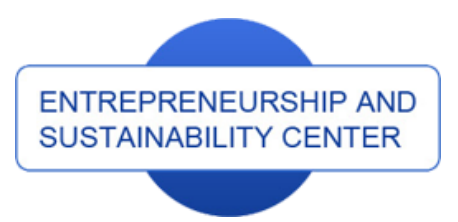

Publisher

$\underline{\text { http://jssidoi.org/esc/home }}$
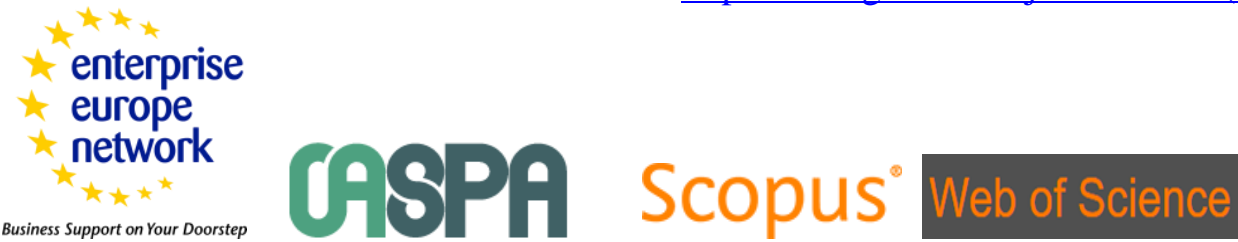

Clarivate
Analytics

\title{
HOW MACRO LEVEL FOUNDATIONS INFLUENCE EMERGING MICRO ENTREPRENEURIAL ACTIVITIES: THE CASE OF SOUTH AFRICA
}

\author{
Rafael Robina-Ramírez ${ }^{1}$, Gert Human ${ }^{2}$ \\ ${ }^{1}$ University of Extremadura, Avda de la Universidad s/n, 10003 Cáceres, Spain \\ ${ }^{2}$ Stellenbosch University, Stellenbosch Central, Stellenbosch, South Africa \\ E-mails: ${ }^{1}$ rrobina@unex.es $;{ }^{2}$ ghuman@sun.ac.za
}

Received 15 October 2019; accepted 19 March 2020; published 30 June 2020

\begin{abstract}
The importance of macro conditions for creating an environment conducive for startups to establish themselves and grow is emphasised. This paper considers the influence of two sets of macro foundations, domestic ecosystems and entrepreneurial networks as well as entrepreneurship education and research, on perceived emerging micro entrepreneurial activity. We show that the domestic ecosystem affects entrepreneurial networks, and together with entrepreneurship education, they have an impact on emerging entrepreneurial activity. Macro entrepreneurial factors also drive emerging entrepreneurial activity directly, and these relationships call for more research.
\end{abstract}

Keywords: entrepreneurship; startups; domestic ecosystem; entrepreneurial network; innovation

Reference to this paper should be made as follows: Robina-Ramírez, R, Human, G. 2019. How macro level foundations influence emerging micro entrepreneurial activities: The case of South Africa. Entrepreneurship and Sustainability Issues, 7(4), 3078-3100. https://doi.org/10.9770/jesi.2020.7.4(34)

JEL Classifications: O11, O12, O44, K2, H1, H2

\section{Introduction}

According to the recent Global Competitive Report 2016/2017, South Africa's economy is nearly at a standstill with GDP growth forecast at just $1.0 \%$ for 2017 and $1.2 \%$ for 2018 . There is persistent weak international demand for its goods and the unemployment rate is higher than 25\% (Schwab 2018, 34).

The situation in South African is made worse when the weak macroeconomic and institutional environments combine with extreme poverty and poor distribution of the economic benefit. According to the "Poverty Trends in South Africa" report, more than 50\% of the population in 2015 is considered poor and earns under the estimated R992 per person per month (pppm) at 2015 prices (Stats SA, 2017:8b). Adding to the lack of economic resources, there is increased business-related crime which has severely affected business in the country (Mbalula, 2017). 


\section{ENTREPRENEURSHIP AND SUSTAINABILITY ISSUES}

ISSN 2345-0282 (online) http://jssidoi.org/jesi/

2020 Volume 7 Number 4 (June)

http://doi.org/10.9770/jesi.2020.7.4(34)

Taken together, this anaemic macro socio-economic scenario affects the markets and ultimately the microenvironment in which entrepreneurs need to operate (Acs et al. 2017).

According to GEM $(2018,2010)$, the factors influencing the micro entrepreneurial environment can be grouped into the following four categories: (a) the domestic ecosystem that concerns, for example, aspects such as government policy and market entry regulations; (b) entrepreneurial networks that typically concern aspects associated with partnerships and cooperation; (c) early entrepreneurship development, which primarily emphasises the importance of entrepreneurship education; and (d) entrepreneurship research which predictably concerns innovation and Africa-specific data challenges.

Although South African emerging entrepreneurial activity has declined by $26 \%$ since 2015 and is at its lowest since 2011, South African startups have increased by around 20\%, because of the rapid advances in technology and digital media (GEM 2018, 7). Such startups concentrate on testing new ideas, products, or services as one type of early-stage entrepreneurial activity (Bosma et al. 2009). They are focused on the life-cycle of an enterprise, where the entrepreneur moves from the idea stage to securing financing, laying down the basic structure of the business, and initiating operations or trading (Smith \& Miner 1983).

South Africa, therefore, deserves our research attention for two reasons. First, as an emerging African economy, South Africa has experienced an increased economic growth after the post-colonial period, yet it remains unable to cope with the socio-economic challenges it faces (Global Entrepreneurship Monitor 2016, 2017). Second, South Africa exhibits comparatively low levels of entrepreneurial activity and this continues to weaken entrepreneurial opportunities and perceptions of entrepreneurial capabilities (GEM 2018). It appears that the rate of entrepreneurial activity in South African (Fairlie 2009) has dropped since 2015. In fact, South Africa is ranked 55th out of 62 economies surveyed with respect to this indicator (GEM 2018, 7). As a result, the business rate is disturbingly low.

Macro business factors in emerging business activity not only are driven by sensitive factors such as; changes in the level of internal political, economic landscape and international economic environment and macroeconomic factors such as market's economic volatility (Naik \& Padhi 2012). Developing economies usually portrays themselves as vulnerable to external investments and prices takers in commodity market. In this scenario, macroeconomic volatility strongly drives the emerging business through fluctuations in the prices of the commodity goods in the export and import relationships.

That fluctuation can cause a financial shock amplifying the effects on the emerging economies (Fernández \& Gulan 2015) through the impact of macro news on exchange rate on emerging economies (Beckmann et al. 2011). Then, existing studies on the relationship between macro factor in emerging business activity should delve into those opposing effect to tackle their negatives consequences in emerging economie (Goldberg 2011; Wongswan 2006).

In the last two decades, wide number of scholars have separately researched about the individual effect of macro and micro factors on startup activity in emerging markets (Duchesneau \& Gartner 2010; Maune 2017; Quinones et al. 1990). However, following the Global Entrepreneurship Monitor's methodology, macro and micro factors are deeply related. The relation between those factors have scarcely studied through causal predictive models.

Structural Equitation Modelling relationship supports oriented goals by explaining and predicting the macro and micro factors on startup activity by maximizing the explained variance of the dependent latent construct. PLSSEM also provides parameters that estimate that maximize the explained variance $\left(\mathrm{R}^{2}\right.$ values) of the dependent constructs. It allows us not only to state the significance of the model and his explained capacity. 


\section{ENTREPRENEURSHIP AND SUSTAINABILITY ISSUES}

ISSN 2345-0282 (online) http://jssidoi.org/jesi/

2020 Volume 7 Number 4 (June)

http://doi.org/10.9770/jesi.2020.7.4(34)

To our knowledge this is the first study that study the relation between macro and micro factors following the GEM's methodologies. The model also gives recommendations to decision-makers to better understand the causal relationships macro and micro factors on startup activity in South Africa.

That is why the contribution of the current paper is two-fold. First, it aims to gain a better understanding of what start-ups see as the macro and micro factors that are influencing them in developing their new businesses. Second, it considers the mediating effect of domestic ecosystems and entrepreneurship education on start-ups entrepreneurial activities.

The structure of the manuscript is unfolded in four sections. First. It is observed several aspects of the literature review such as; the South Africa macro factors, South African domestic entrepreneurial ecosystem, entrepreneurial network, educational challenges in South Africa, entrepreneurship research: Innovation and data research. Second.The paper delved into the methodology. In the third and fourth section are Results and Conclusions.

\section{Literature review}

\subsection{South Africa macro factors}

In South Africa, since the "Bill of Rights" was approved, the constitution has focused on the most disadvantaged sectors of the population and laid the foundation for restructuring the welfare system according to principles of justice and equity (Patel 2015). To achieve both economic growth and social redistribution, social and economic policies were a priority (Van Niekerk 2013). Thus, a subsequent macro-economic policy, the Growth, Employment and Redistribution programme (GEAR) adopted in 1997, was an attempt to attract foreign investment, regenerate economic growth, liberalise the economy, and reduce the country's debt that was inherited from the apartheid era (Ho 2019). However, economic growth declined sharply after the global economic crisis of 2009, and between 1993 and 2017 South Africa recorded on average GDP growth rate of 2.3\% (Trading Economics, 2018).

The country's constitution has served to create an expectation of solidarity among the citizenry that their needs should be met by the state (Murray Li 2016). The reality is that the unemployment rate is 35\% of the labour force in South Africa (Stats SA 2017a), and social and economic policy has resulted in a relatively jobless growth path characterised by high labour costs (Webster 2013). From a macro perspective, South African entrepreneurs not only have to deal with economically disadvantageous conditions (Du Toit 2004) but also social ones such as poverty (Rogerson 2018) and violence (Crush \& Peberdy 2018) that influence emerging micro entrepreneurial activities.

Such social and economic policies have shaped entrepreneurial framework conditions (EFCs) (GEM, 2018, 10). They affect key aspects such as entrepreneurial finance, entrepreneurship programmes, taxes and bureaucracy, cultural and social norms, commercial and legal infrastructure, and internal market dynamics. Institutional factors such as an independent judiciary system and an adequate national security system were also found to have a positive and significant influence on entrepreneurs in emerging markets (Urban \& Hwindingwi 2016).

What is needed is a favourable environment that combines political, social, economic, and educational factors (Timmons 1994). Prosperous countries that developed their business cultures in the late twentieth century have had in common strong attitudes toward micro entrepreneurial activities based on innovation, technology, and products (Bateman 1997).

Micro entrepreneurial activities, as part of the entrepreneurial ecosystem, have gained prominence during the last five years, but their definition is not yet widely shared (Stam 2015). Whereas, being "entrepreneurial" refers to 


\section{ENTREPRENEURSHIP AND SUSTAINABILITY ISSUES}

ISSN 2345-0282 (online) http://jssidoi.org/jesi/

2020 Volume 7 Number 4 (June)

http://doi.org/10.9770/jesi.2020.7.4(34)

creating unexplored goods and services (Shane \& Venkataraman 2000), and "entrepreneurial ecosystem" narrows down the agglomeration to the interactions between players in a certain region (Freiling \& Baron 2017). This approach implies that individuals (actors) and organisations (firms and institutions) interact and new start-ups are developed in the process (Stam 2014). Thus, the ecosystem is orientated toward entrepreneurial endeavours (Henrekson \& Sanandaji 2014) and innovative start-ups (Baumol 1993). In this system, entrepreneurs are the key pins that bring together the domains of policy-makers, finance, cultural support, human capital, and network interaction (Isenberg 2010).

The entrepreneurial activities associated with the emergence of start-ups are known to follow a relatively predictable pattern that seems to start with an early entrepreneurial idea, and this evolves into the more formalized activities of setting up a business (Stam et al. 2012). During the early stage, entrepreneurial activity is initially very concerned with developing and testing products rather than making a profit. It is argued that during this stage, the entrepreneur's high need for achievement (Rauch \& Frese 2000) and risk-taking propensity (Timmons et al. 1985) combine with entrepreneur personality characteristics such as proactivity (Becherer \& Maurer 1999) and personal initiative (Frese 1998). The latter phenomenon benefits from a profound body of knowledge developed during the last three decades, and it is still expanding. More relevant to the current study is that earlystage entrepreneurs and startups need standardised institutional support and a stable economy to grow and establish their business (North 1990).

In the case of South Africa, the data from the 2017 Global Entrepreneurship Monitor (GEM 2017, 6) survey seems to suggest that policy reforms are needed if the institutional support hopes to reverse the weak South African business environment. This is particularly relevant for small and medium-sized enterprises that are often expected to make more substantial contributions to the country's dire employment situation. To confirm the perceived situation, we hypothesise the following:

\subsection{South African domestic entrepreneurial ecosystem}

According to the World Economic Forum (2013), the entrepreneurial ecosystem is organised according to three key factors: resources (finance and human capital), formal institutions (government, education and market), and informal institutions (cultural support). It is reported that the effect of the entrepreneurial ecosystem is largely dependent on entrepreneurship education and new opportunities for innovation through emerging networks (GEM 2018). Similarly, the literature also suggests that the availability of market data (Debortoli et al. 2014), and the level of strategic partnering and cooperation (Klueter \& Rosenkopf, 2013) exhibit similar influences on the entrepreneurial ecosystem.

In the domestic ecosystem, micro entrepreneurs have to deal with government policies which can influence new businesses depending on the institutional culture orientation toward entrepreneurship (La Porta et al. 2008). Regulations in developing and developed countries are built by democratic political institutions (Klasing 2013). When those policies are taken over by oligarch politicians, then the foundations of the rules of law and other norms of governance can be negatively affected (Acemoglu 2008) - as well as the expansion of entrepreneurship opportunities (Munemo, 2012). Essentially, three institutional factors make it more difficult: limited access to local credit, complex tax laws, and corruption (Schwab 2018, 34).

As part of the entrepreneurial domestic ecosystem, commercial credit, equity financing or supplier financing have become serious issues for keeping startups going (Upstart Business Strategies 2006). Basic infrastructure such as reliable and cost-efficient electricity and water are also essential factors for entrepreneurs (Winkler et al. 2011), and both factors are impeding the emerging entrepreneur in South Africa (Olawale, Garwe 2010). 


\section{ENTREPRENEURSHIP AND SUSTAINABILITY ISSUES}

ISSN 2345-0282 (online) http://jssidoi.org/jesi/

2020 Volume 7 Number 4 (June)

http://doi.org/10.9770/jesi.2020.7.4(34)

In the case of South Africa, regulations have also severely hampered new, proactive business startups (Estrin \& Prevezer 2010). Unfortunately, the lack of competence in South African companies ends up in business conflicts affecting the quality and cost of the products and services (Ahlquist \& Prakash 2010). The South African government has encouraged some strategies to promote entrepreneurs and small businesses. In January 2006, the South African government launched the Joint Initiative on Priority Skill Acquisition (JIPSA) for entrepreneurs (Mlambo-Ngcuka 2006, 5) that was led by the Deputy President. Public service delivery and developing better infrastructure, information, communication, and technologies have been the mission of the programme. After being completed, JIPSA was unsuccessful for entrepreneurs because of the inefficient regulatory ecosystem (Upstart Business Strategies 2006).

The startup entrepreneurial ecosystem in South Africa have not adequately benefitted from research that adopted a macro view of the entire system. That ecosystem includes the so-called domestic ecosystem, the entrepreneurial network, and educational and research interface to promote entrepreneurship. Therefore, our study aims to understand how the South African ecosystem works as a key factor for developing emerging entrepreneur activities (Acs et al. 2017). Therefore, the following is hypothesised:

Hypothesis $1\left(\mathrm{H}_{1}\right)$ : The South African Domestic Ecosystem (DE) negatively influences Emerging Micro Entrepreneurial Activities (EEA).

\subsection{Entrepreneurial network}

South Africa benefits from diverse human cultures allowing the country to internationalise businesses through cooperation and strategic partnerships among entrepreneurs (GEM 2018). The evidence suggests that this networking and partnering notion has recently pushed startups to expand internationally. This is commonly the style of management among startups (Weiblen \& Chesbrough, 2015).

This international governance role is addressed by framing the political agenda and prioritising key issues in countries (Jones \& Baumgartner 2005). Political actors and scientific and professional experts interact with local entrepreneurs to promote cooperation and strategic partnerships (Béland 2005). These organisations lead the elite, who facilitate the knowledge and drivers to guide domestic entrepreneurs, to promote international partnership and cooperation among networks and organisations.

However, South African international partnership and cooperation have made the network very challenging for entrepreneurs because of the lack of trust in international competition, low competitiveness, and state protectionism (Moodley 2003). This is not surprising because other emerging markets show similar conditions as Sánchez \& Lehnert (2018) demonstrated for Mexico and Peru.

To improve the South African entrepreneurship network, the government needs to train the entrepreneurial ambitious people to evolve their skills and knowledge by being an active part of entrepreneurial projects undertaken based on the entrepreneurial endeavour (Murdock \& Varnes 2018). Entrepreneurs need to actively and skilfully engage in the rapidly internationalising business environment by promoting strategic partnerships and cooperation in terms of subsidiaries, joint ventures, outsourcing, import-and-export links, technology transfer, and business sharing, among others (Tesfayohannes 2012).

Business interaction can be enhanced by rewarding a cooperative policies network such as by reducing the import barriers or taxes to enable African entrepreneurs to expand the impact of their business beyond domestic domains. Prospective scholarly research needs to improve the citizens' understanding about the effects of network evolution on the entrepreneurial trajectory toward business internationalization (Zengyu Huang et al. 2013).

This process of internationalisation through social-tech startups appears to follow three distinct stages: (1) learning, (2) emulation, and (3) competition. First, the learning stage provides full or limited information or 


\section{ENTREPRENEURSHIP AND SUSTAINABILITY ISSUES}

ISSN 2345-0282 (online) http://jssidoi.org/jesi/

2020 Volume 7 Number 4 (June)

http://doi.org/10.9770/jesi.2020.7.4(34)

experience from other countries (Meseguer 2005). Second, emulation adopts successful policies to build a transnational social-tech network led by competitive professionals (Hass 1992). And third, competition addresses how cooperation and strategic partnerships manage the pressure from equal or asymmetric economies (Damro 2012).

Unfortunately, those three social-tech networks are very limited in South Africa, because of the low level of technological and science skills in the vast majority of the population (Olawale \& Garwe 2010). The high cost of new technology, which is beyond the means of many small businesses, also has a negative effect on entrepreneurs (Walker \& Mkwananzi 2015). According to GEM (2018), just over half (55\%) of early-stage entrepreneurs in South Africa use the latest or new technology, compared to an average of $45 \%$ for the Africa region. A quarter of South African entrepreneurs use the very latest technology, which does not compare favourably with other countries (GEM 2018). Therefore, the following are hypothesised:

Hypothesis $2\left(\mathrm{H}_{2}\right)$ : The South African Domestic Ecosystem (DE) negatively influences the South African Entrepreneurial Network (NE).

Hypothesis $3\left(\mathrm{H}_{3}\right)$ : The South African Entrepreneurial Network (NE) negatively influences Emerging Micro Entrepreneurial Activities (EEA).

\subsection{Educational challenges in South Africa}

Education strategy and programmes are key factors for improving an economy as well as self-employment (Sullivan 2000). According to Gouws (2002), the key to success in establishing a culture of entrepreneurship in South Africa is education, through which government can promote the establishment and growth of entrepreneurs (Luiz 2002).

The education system must enable in-school youth to develop entrepreneurial characteristics and competencies as early as possible. This will equip more young people with the competencies and skills to become job creators rather than just be job seekers.

According to the Youth Enterprise Development Strategy (2013-2023), the South African government intends to foster youth economic participation by deliberately enhancing and accelerating youth entrepreneurship that is capable of contributing to the gross domestic product (GDP) growth rate (Department of Trade and Industry 2013). However, according to Von Broembsen et al. (2005:36), most South African youth do not believe they have the skills to start a business, and this may be attributed to the low proportion of South Africans that have completed secondary education. In South Africa, entrepreneurship education to set up new business as startups is still one of the prime factors limiting its economic growth (Ikebuaku \& Dinbabo, 2018) due to weak training in primary and secondary schools, and post-school entrepreneurship has declined since 2015 (GEM 2018, 10).

Despite the large number of entrepreneurship training programmes offered in South Africa, very few have well designed monitoring and evaluation programmes to assess their impact (Isaacs et al. 2007). Despite these good intentions, we focus on the current situation in South Africa and hypothesise the following:

Hypothesis $4\left(\mathrm{H}_{4}\right)$ : South African Entrepreneurship Education (EE) negatively influences Emerging Micro Entrepreneurial Activities (EEA).

Hypothesis $5\left(\mathrm{H}_{5}\right)$ : South African Entrepreneurship Education (EE) negatively influences South African Entrepreneurship Research (ER). 


\section{ENTREPRENEURSHIP AND SUSTAINABILITY ISSUES}

ISSN 2345-0282 (online) http://jssidoi.org/jesi/

2020 Volume 7 Number 4 (June)

http://doi.org/10.9770/jesi.2020.7.4(34)

\subsection{Entrepreneurship research: Innovation and data research}

Data research, as a relatively recent phenomenon, can assist entrepreneurs to find answers to many questions. Until now, studies that attempt to measure entrepreneurship and innovation were based on subjective measures of perceptions that cover attitudes and activities of entrepreneurs (Wong \& Autio, 2005).

Data research can be used to gain insights into social networks and understand the underlying trends observed in the interaction that takes place in the network. It is even argued that such data-processing capabilities can explain phenomena beyond what any human can currently predict (Pentland 2014).

New insights and findings from analytics have proven very useful for making predictions on consumer attitudes (Agrawal et al. 2016). Moreover, technology is shaping the new trends to change the rules of management and supply chain management. Not surprisingly, some suggest that traditional models of production and distribution will become obsolete as additive technologies and digitisation will better predict outcomes (Waller \& Fawcett, 2013).

According to George et al. (2014), entrepreneurs can get advantages from five types of data: (1) public data provided by governmental institutions that can be used for management applications; (2) private data that belong to private firms, such as consumer transactions and mobile phone usage; (3) non-core data that are passively collected to be recombined with other data sources to create new value for entrepreneurs; (4) community data for capturing social trends through unstructured data - such as Twitter or online purchases (Kennedy, 2008); and (5) self-quantification data, which are revealed by entrepreneurs through quantifying personal behaviours. These mechanisms of value creation provide a new business model and new governance tools (Robina-Ramirez et al. 2019). Data analytics is currently offering commercial services to identify business patterns in new markets and product categories.

In the case of the African countries, there are currently very limited data on African entrepreneurs and firm ownership (Lepoutre et al. 2013). The lack of appropriate entrepreneurial ecosystems has led to very limited data about African entrepreneurs and firm ownership. This information will be useful for the government to formulate improved policies to nurture entrepreneurs and businesses and to track the performance of the small business sector from an African perspective. Thus, it can capture exponential value not only for governments but also for businesses and communities (McKinsey Global Institute 2011). These observations in the extant literature facilitate the construction of the following hypothesis:

Hypothesis $6\left(\mathrm{H}_{6}\right)$ : South African Entrepreneurship Research (ER) negatively influences Emerging Micro Entrepreneurial Activities (EEA).

These hypotheses allowed for the construction of a theoretical framework, which is depicted in Figure 1. The underlying notion of the framework is that perceptions of startup activity are influenced by perceptions regarding the favourability of general macroeconomic conditions, the domestic business ecosystem, and the entrepreneurial network on the one hand and the perception of entrepreneurship education and research in the country on the other hand. 


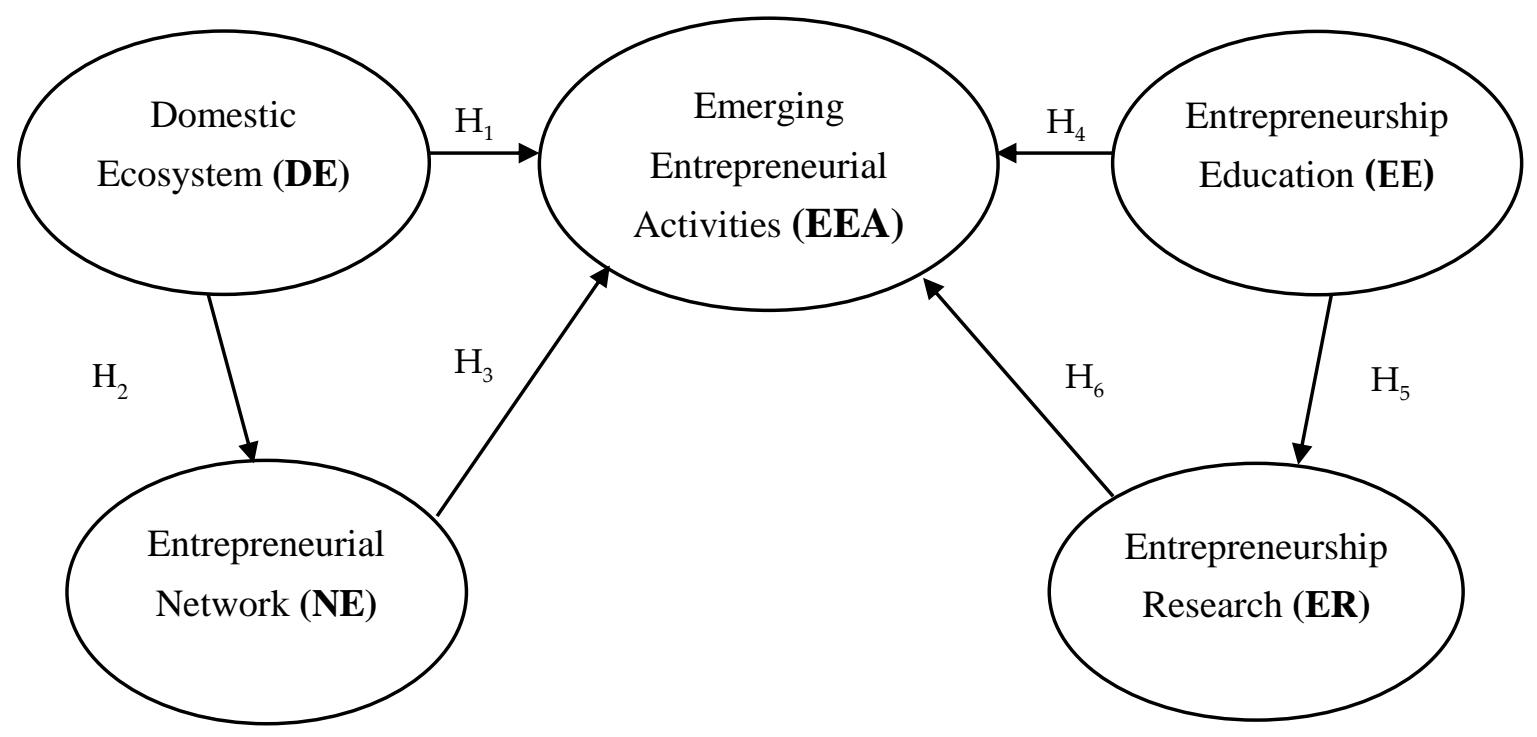

Figure 1. South African emerging entrepreneurial activities.

Own source

\section{Methodology}

Consistent with key authors (Morris et al. 2010; Zhao et al. 2013) we used existing published scales to compile a 34 items scale that measures the contructs in the theoretical model. In order to improve the measurement instrument, we have pre-tested all 34 indicator items for face validity in five startup companies in South Africa. The five firms were very diverse and included high tech startups like biomedical engineering, a media technology company, a rural solar power company, an occupational health company, and an environmentally friendly construction firm that installs and designs PVC fences that are highly durable and environmentally friendly.

The pretested firms were asked to respond to the original 34-item scale and to discuss their answers and the statement questions with the interviewers. This approach ensured that any unclear items were rephrased, while others were removed. We eliminated 10 items across 4 of the latent variables, thus leaving a final scale consisting of 24 items. The interviews also revealed that time is a serious issue for startups, and therefore the final questionnaire should be as short as possible. This finding is consistent with the notion of respondent fatigue (Rodgers et al. 2018), which is often cited in emerging market contexts. The pre-test also provided valuable insights in terms of entrepreneur familiarity with business language, and therefore it was decided to keep the language used in the questionnaire as simple as possible, while representing a South African tongue. Therefore, statements were formulated in simple language (Table 1), and a 10-point Likert type scale was used to measure the respondents' level of agreement.

Prior to administering the survey and starting data collection, the questions were submitted to other South African entrepreneurship scientists to solicit their comments on the appropriateness of the items. This process yielded only minor changes and led to activation of the data-collection process. Thus, data collection was done via an online survey based on a 10-point scale of 24 items, along with other descriptive questions. Between November 2018 and March 2019, the research team contacted the startups included in the original list twice a week by email, 
ENTREPRENEURSHIP AND SUSTAINABILITY ISSUES

ISSN 2345-0282 (online) http://jssidoi.org/jesi/

2020 Volume 7 Number 4 (June)

http://doi.org/10.9770/jesi.2020.7.4(34)

sending the questionnaire in Google Docs. The final survey (Table 1) consisted of 24 items: Emerging Micro Entrepreneurial Activities (EEA) = 5 items (based on Watson et al. 1998; Van Gelderen et al. 2005); General Macro Entrepreneurial Factors (GMEF) = 3 items (based on GEM, 2018; Shane, Venkataraman, 2000; Isenberg, 2010); Domestic Ecosystems (DE) $=7$ items (based on Scott \& Meyer, 1984; Klasing, 2013); Entrepreneurial Networks (NE) $=3$ items (based on Weiblen, Chesbrough 2015); Entrepreneurship Education (EE) $=3$ items (based on Gouws 2002; Luiz 2002, 68); and Entrepreneurship Research (ER) = 3 items (based on George et al. 2014; Lepoutre, 2013). Based on information from web sources, government sources, and business associations, the research team developed a non-probability database of 211 potential startups. Thus, consistent with the methodological recommendations by Malhotra (2019) and Uprichard (2013) we employed a non-probability sampling approach based on the database of startups that the authors were able to construct. Thereafter data was collected using an electronic version of the measurement instrument. Once the data were collected and cleaned by removing incomplete responses, a total of $118(56 \%)$ useable responses were available for analysis. Given the claimed suitability of variance-based structural equation modelling for smaller and skewed sample distributions (Chin 1998; Chin et al. 2003; Hair et al. 2019), it was decided to subject the data to a latent variable modelling procedure using SmartPLS 3.0 (Ringle et al. 2015), because this remains a prominent procedure in leading journals (Sarstedt et al. 2016).

Table 1. Research Instrument and Measurement Model

\begin{tabular}{|c|c|c|}
\hline Latent Variable & Indicators & CODE \\
\hline \multirow{5}{*}{$\begin{array}{l}\text { Emerging Micro } \\
\text { Entrepreneurial } \\
\text { Activities (EEA) }\end{array}$} & $\begin{array}{l}\text { Accessing the regulatory stakeholder network such as governments, trade, or } \\
\text { labour organisations that will be important for establishing the new venture }\end{array}$ & EEA1 \\
\hline & $\begin{array}{l}\text { Developing the business model to identify sources of revenue, the intended } \\
\text { customer base, products, and details of financing }\end{array}$ & EEA2 \\
\hline & Securing financial backing for the new venture & EEA3 \\
\hline & Acquiring the necessary knowledge and skills to establish the new venture & EEA4 \\
\hline & Establishing a new market or gaining access to an existing market & EEA5 \\
\hline \multirow[t]{7}{*}{$\begin{array}{l}\text { Domestic Ecosystem } \\
\text { (DE) }\end{array}$} & $\begin{array}{l}\text { The challenge to get access to capital is a major limitation to emerging } \\
\text { entrepreneurship in South Africa }\end{array}$ & DE1 \\
\hline & $\begin{array}{l}\text { Government and political corruption is a major threat to emerging } \\
\text { entrepreneurship in South Africa }\end{array}$ & DE2 \\
\hline & $\begin{array}{l}\text { Private sector and economic corruption is a major threat to emerging } \\
\text { entrepreneurship in South Africa }\end{array}$ & DE3 \\
\hline & $\begin{array}{l}\text { Inadequate infrastructure (electricity, roads, water sanitation) is a major threat to } \\
\text { emerging entrepreneurship in South Africa }\end{array}$ & DE4 \\
\hline & $\begin{array}{l}\text { The poor condition of infrastructure (electricity, roads, water sanitation) is a major } \\
\text { threat to emerging entrepreneurship in South Africa. }\end{array}$ & DE5 \\
\hline & $\begin{array}{l}\text { Labour market regulation is a major threat to emerging entrepreneurship in South } \\
\text { Africa }\end{array}$ & DE6 \\
\hline & $\begin{array}{l}\text { Labour market instability is a major threat to emerging entrepreneurship in South } \\
\text { Africa }\end{array}$ & DE7 \\
\hline \multirow{3}{*}{$\begin{array}{l}\text { Entrepreneurial } \\
\text { Network (NE) }\end{array}$} & The extent of cooperation between private sector companies & NE1 \\
\hline & The competitiveness of South African companies & NE4 \\
\hline & The status of technological development in the country & NE5 \\
\hline \multirow{3}{*}{$\begin{array}{l}\text { Entrepreneurship } \\
\text { Education (EE) }\end{array}$} & The state of the educational system in general & EE1 \\
\hline & $\begin{array}{l}\text { The extent to which entrepreneurial competencies are developed in the current } \\
\text { educational system }\end{array}$ & EE2 \\
\hline & The extent to which entrepreneurship is part of the school curriculum & EE3 \\
\hline \multirow{3}{*}{$\begin{array}{l}\text { Entrepreneurship } \\
\text { Research (ER) }\end{array}$} & The level of research that leads to new innovations in South Africa & ER1 \\
\hline & $\begin{array}{l}\text { The level of access that entrepreneurs have to research capabilities, data, and } \\
\text { results in educational institutions }\end{array}$ & ER2 \\
\hline & $\begin{array}{l}\text { The willingness of companies to share research and development information with } \\
\text { entrepreneurs }\end{array}$ & ER3 \\
\hline
\end{tabular}

Own source 
ENTREPRENEURSHIP AND SUSTAINABILITY ISSUES

ISSN 2345-0282 (online) http://jssidoi.org/jesi/

2020 Volume 7 Number 4 (June)

http://doi.org/10.9770/jesi.2020.7.4(34)

\section{Results}

This study focused particularly on startup firms in South Africa. All (100\%) the respondents classified themselves as startup firms, and $92 \%$ of the respondents indicated that their startup business was located inside the borders of South Africa. Respondents that indicated that although they may be South African citizens, their businesses were located outside South Africa, were removed from the data set. Most (60\%) of respondents indicated that they operate in information technology and telecommunications-related industries. Other industries included agriculture, biotechnology, entertainment, security services, travel and leisure, and waste management. Also, not surprisingly, the products developed by these companies mostly relate to financial services and digital solutions which represented 55\% of respondents. Most of the startup companies included in the survey were based in Cape Town (45\%) and Johannesburg (43\%); while the other respondents were located in other larger metropolitan areas, including Pretoria, Durban, and Port Elizabeth. It is also worth noting that $28 \%$ of the startup companies in the survey are currently part of an incubator. In addition, most respondents were male (94\%), 32\% were aged 26 35 years, $26 \% 46$ - 55 years, and 23\% 36 - 45 years. In total, $94 \%$ of respondents were less than 55 years of age.

It was encouraging to note that $36 \%$ of the respondents held honours degrees (the equivalent of a four-year bachelor's degree in other countries), while $34 \%$ had master's degrees. Therefore, the sample is considered to be well educated. Another aspect that may play an important role in participant responses is their experience. As much as 53\% indicated that they had prior startup experience, and 13\% indicated that the current startup was either their third or fourth attempt. In addition, $71 \%$ of the respondents reported that they were formerly employed in the private sector, thereby further enhancing their experience in business. The measurement model, employing only reflective measures, yielded satisfactory results as all items loaded as expected (Table 2) and were significant at the $\mathrm{p}<0.05$ level:

Table 2. Measurement model

\begin{tabular}{|l|c|c|c|c|c|}
\hline & DE & EE & ER & EEA & NE \\
\hline DE1 & $\mathbf{0 . 9 2 6}$ & 0.608 & 0.310 & 0.481 & 0.653 \\
\hline DE2 & $\mathbf{0 . 8 7 5}$ & 0.532 & 0.409 & 0.604 & 0.611 \\
\hline DE3 & $\mathbf{0 . 8 0 6}$ & 0.526 & 0.263 & 0.483 & 0.616 \\
\hline DE4 & $\mathbf{0 . 8 3 6}$ & 0.527 & 0.362 & 0.500 & 0.555 \\
\hline DE5 & $\mathbf{0 . 9 0 7}$ & 0.491 & 0.341 & 0.508 & 0.594 \\
\hline DE6 & $\mathbf{0 . 7 6 9}$ & 0.508 & 0.257 & 0.477 & 0.522 \\
\hline DE7 & $\mathbf{0 . 8 3 2}$ & 0.481 & 0.425 & 0.543 & 0.583 \\
\hline EE1 & 0.538 & $\mathbf{0 . 9 0 2}$ & 0.359 & 0.540 & 0.640 \\
\hline EE2 & 0.553 & $\mathbf{0 . 8 9 5}$ & 0.478 & 0.678 & 0.578 \\
\hline EE3 & 0.567 & $\mathbf{0 . 8 9 6}$ & 0.424 & 0.625 & 0.667 \\
\hline ER1 & 0.369 & 0.446 & $\mathbf{0 . 9 1 4}$ & 0.648 & 0.344 \\
\hline ER2 & 0.361 & 0.418 & $\mathbf{0 . 9 5 9}$ & 0.558 & 0.355 \\
\hline ER3 & 0.385 & 0.457 & $\mathbf{0 . 9 2 0}$ & 0.534 & 0.370 \\
\hline EEA1 & 0.494 & 0.537 & 0.584 & $\mathbf{0 . 8 9 0}$ & 0.449 \\
\hline EEA2 & 0.588 & 0.643 & 0.612 & $\mathbf{0 . 8 9 8}$ & 0.634 \\
\hline EEA3 & 0.532 & 0.620 & 0.513 & $\mathbf{0 . 8 9 1}$ & 0.562 \\
\hline EEA4 & 0.459 & 0.526 & 0.567 & $\mathbf{0 . 8 4 7}$ & 0.487 \\
\hline EEA5 & 0.566 & 0.691 & 0.456 & $\mathbf{0 . 8 4 4}$ & 0.652 \\
\hline NE1 & 0.647 & 0.579 & 0.314 & 0.540 & $\mathbf{0 . 9 2 4}$ \\
\hline NE4 & 0.544 & 0.688 & 0.331 & 0.586 & $\mathbf{0 . 9 0 2}$ \\
\hline NE5 & 0.668 & 0.609 & 0.379 & 0.586 & $\mathbf{0 . 8 6 1}$ \\
\hline
\end{tabular}

Own source 
In addition, the measurement also exhibits satisfactory reliability (Table 3) with Cronbach's alpha coefficient and composite reliability exceeding the 0.7 benchmark (Hair et al. 2017). Discriminant validity is also supported by the AVE scores that are all above the 0.5 (Bagozzi, Yi, 1988) benchmark.

Table 3. Measurement reliability and validity diagnostics

\begin{tabular}{|l|c|c|c|}
\hline & $\begin{array}{c}\text { Cronbach's } \\
\text { Alpha }\end{array}$ & $\begin{array}{c}\text { Composite } \\
\text { Reliability }\end{array}$ & $\begin{array}{c}\text { Average Variance } \\
\text { Extracted (AVE) }\end{array}$ \\
\hline Domestic Ecosystem (DE) & 0.936 & 0.949 & 0.726 \\
\hline Entrepreneurship Education (EE) & 0.881 & 0.926 & 0.806 \\
\hline Entrepreneurship Research (ER) & 0.923 & 0.951 & 0.867 \\
\hline Emerging Micro Economic Activities (EEA) & 0.923 & 0.942 & 0.764 \\
\hline Entrepreneurial Networks (NE) & 0.877 & 0.924 & 0.803 \\
\hline
\end{tabular}

Own source

Discriminant validity was further confirmed by the Fornell and Larcker (1981) method and the HeterotraitMonotrait (Henseler et al. 2014) method. The Fornell and Larcker method (Fornell, Larcker, 1981) compares the square root of the AVE in the diagonal with the correlation coefficients in the same row and column for each construct. Table 4 (below) shows that the square root of AVE scores exceeds all row and column values, thus suggesting discriminant validity. The HTMT method employs a comparison of the heterotrait-heteromethod correlations and monotrait-monomethod correlations.

Table 4. Fornell and Larcker assessment of Discriminant validity

\begin{tabular}{|l|c|c|c|c|c|}
\hline Constructs & DE & EE & ER & EEA & NE \\
\hline DE & $\mathbf{0 . 8 5 2}$ & & & & \\
\hline EE & 0.616 & $\mathbf{0 . 8 9 8}$ & & & \\
\hline ER & 0.399 & 0.474 & $\mathbf{0 . 9 3 1}$ & & \\
\hline EEA & 0.605 & 0.691 & 0.626 & $\mathbf{0 . 8 7 4}$ & \\
\hline NE & 0.695 & 0.697 & 0.383 & 0.638 & $\mathbf{0 . 8 9 6}$ \\
\hline
\end{tabular}

Note: Square root of AVE on diagonal

Own source

When the HTMT value is below 0.90 (Teo et al. 2008) or 0.85 (Kline 2011) - then discriminant validity is established between two constructs. Therefore, as shown in Table 5 (below), our measure exhibits satisfactory discriminant validity. 
Table 5. HTMT assessment of discriminant validity

\begin{tabular}{|l|c|c|c|c|}
\hline & DE & EE & ER & EEA \\
\hline EE & 0.678 & & & \\
\hline ER & 0.427 & 0.518 & & \\
\hline EEA & 0.649 & 0.758 & 0.674 & \\
\hline NE & 0.763 & 0.797 & 0.424 & 0.707 \\
\hline
\end{tabular}

Own source

The satisfactory performance of the measurement model allowed for consideration of the structural model and the hypothesised relationships between constructs. Consistent with the recommendations of Hair et al. (2019) we first consider collinearity. All constructs exhibit VIF values less than 3 (table 6); thus, suggesting that our data does not suffer from collinearity issues. Second, the combined effect of domestic ecosystems (DE), entrepreneurial networks (EN), entrepreneurship education (EE), and research in entrepreneurship (ER) explain 75\% (adjusted $\mathrm{R}^{2}$ $=0.748$ ) of the emerging entrepreneurial activities (EEA). According to Hair et al. (2019) this can be considered "substantial" statistical power. The results also showed that entrepreneurship education (EE) is a "weak" contributor $\left(22 \%\right.$ - adjusted $\left.\mathrm{R}^{2}=0.224\right)$ to the variance $\mathrm{ER}$, while almost $50 \%$ (adjusted $\mathrm{R}^{2}=0.482$ ) of the variance in entrepreneurial networks (EN) is explained by the perceived state of the domestic ecosystem (DE). The latter 50\% is considered a "moderate" contribution (Hair et al. 2019).

Table 6. Collinearity statistics*

\begin{tabular}{|l|c|c|c|}
\hline & EEA & ER & NE \\
\hline DE & 2.106 & & 1.000 \\
\hline EE & 2.254 & 1.000 & \\
\hline ER & 1.321 & & \\
\hline NE & 2.499 & & \\
\hline
\end{tabular}

*VIF values

Own source

Thirdly, a clearer picture of predictive accuracy emerges from inspecting the $\mathrm{Q}^{2}$ values in the PLSpredict procedure in Table 7. The $\mathrm{Q}^{2}$ values (table 7) ranges between 0.149 and 0.468 , suggesting medium predictive accuracy of the model. Fourthly, the PLSpredict procedure also generates Root Mean Squared Error (RMSE) as well as Mean Absolute Error (MAE) statistics for dependent contruct indicators, applied to the theorised PLS model and a system generated simple linear model. According to Hair, et al. (2019) researchers can then compare the RMSE and MAE values between the two models as a further assessment of predictive power of the model. From Table 7 it is clear that in the minority of the cases the RMSE and MAE values are higher in the linear model, thus suggesting the model exhibits meduim predictive power. 
Table 7. Predictive accuracy

\begin{tabular}{|c|c|c|c|c|c|}
\cline { 3 - 5 } \multicolumn{2}{c|}{} & \multicolumn{2}{c|}{ PLS Model } & \multicolumn{2}{c|}{ Linear Model } \\
\hline Dependent contruct indicators & Q $^{2}$ predict & RMSE & MAE & RMSE & MAE \\
\hline EEA1 & 0.306 & 1.373 & 1.112 & 1.430 & 0.959 \\
\hline EEA2 & 0.444 & 1.184 & 0.952 & 1.189 & 0.968 \\
\hline EEA3 & 0.396 & 1.315 & 1.110 & 1.225 & 1.201 \\
\hline EEA4 & 0.281 & 1.464 & 1.143 & 1.297 & 0.962 \\
\hline EEA5 & 0.468 & 1.407 & 1.098 & 1.471 & 1.181 \\
\hline ER1 & 0.172 & 1.491 & 1.189 & 1.511 & 1.190 \\
\hline ER2 & 0.149 & 1.620 & 1.297 & 1.607 & 1.267 \\
\hline ER3 & 0.185 & 1.639 & 1.307 & 1.666 & 1.308 \\
\hline NE1 & 0.407 & 1.578 & 1.100 & 1.607 & 1.140 \\
\hline NE4 & 0.274 & 1.738 & 1.309 & 1.618 & 1.219 \\
\hline NE5 & 0.430 & 1.417 & 1.062 & 1.425 & 1.073 \\
\hline
\end{tabular}

Own source

The satisfactory results of the fours analisis above facilitates the final consideration of the hypothesis hypothesis. Our results (Table 8, below) showed that a single hypothesis, H1, which proposed that the South African Domestic Ecosystem (DE) negatively influences South African Emerging Entrepreneurial Activities (EEA), could not be supported.

Table 8. Structural model and hypothesis testing

\begin{tabular}{|l|l|c|c|l|}
\hline Hypothesis & \multicolumn{1}{|c|}{ Relationship } & $\begin{array}{c}\text { Standardised } \\
\text { Coefficients } \\
\mathbf{( \beta )}\end{array}$ & t-statistic & Results \\
\hline H1 & DE -> EEA & -0.049 & 0.548 & Not supported \\
\hline H2 & DE -> NE & 0.695 & 14.368 & Supported \\
\hline H3 & NE -> EEA & 0.152 & 2.275 & Supported \\
\hline H4 & EE -> EEA & 0.306 & 3.442 & Supported \\
\hline H5 & EE -> ER & 0.474 & 6.751 & Supported \\
\hline H6 & ER -> EEA & 0.162 & 2.330 & Supported \\
\hline
\end{tabular}

Own source

The results for the remaining hypotheses $(\mathrm{H} 2-\mathrm{H} 6)$ were all supported at the $\mathrm{p}<0.05$ confidence level. Thus, our results confirm that, as perceived by owners of startup businesses, the macro economic factors in South Africa negatively influence Emerging Entrepreneurial Activities (EEA) in the country.

These micro-level entrepreneurial activities (EEA) are also perceived to be negatively influenced by the country's entrepreneurial networks (EN), the perceived state of entrepreneurship education (EE), and the perceived state of entrepreneurship research (ER). Moreover, the results also showed that the respondents' perception of the South African Domestic Ecosystem (DE) negatively influences their perception of the country's Entrepreneurial 


\section{ENTREPRENEURSHIP AND SUSTAINABILITY ISSUES}

ISSN 2345-0282 (online) http://jssidoi.org/jesi/

2020 Volume 7 Number 4 (June)

http://doi.org/10.9770/jesi.2020.7.4(34)

Networks (NE) and that the perceived state of Entrepreneurship Education (EE) negatively influences perceived Entrepreneurship Research (ER) in South African institutions.

\section{Discussion}

According to international organizations as World Economic Forum, Wold Band and United Nations stable and fundamental conditions such as; macro-economic stability, labour market, education, infrastructure, market efficiency is required for the well-functioning business environment (Schwab 2018). Those fundamental conditions were shaken the emerging economies since the last financial crisis in US 2007/2008. The global downturn (2008-2012) effectively dragged South Africa economy behind most of the African countries (OCDE 2014).

Data seem to suggest that macro factors do remain an important driver in how emerging entrepreneurial activities are perceived, start-ups' perceptions of South African Macro Entrepreneurial Factors negatively impact perceptions about the ease of micro entrepreneurial activities EEA.

Especially dramatic in the rate of youth unemployment, over $65 \%$ are living in under-employment conditions, situation that has been described as a "tiching tie bomb" (Herrington et al. 2014).

The South Africa macroeconomic-institutional environment combines the alarming extreme poverty (Stats SA 2017:8b), increased business-related crime (Mbalula 2017) and high level of corruption (Estrin et al. 2013) with a high unemployment rate. It can be as high as 45\% (depending on the method of measurement) (Schwab 2018).

With this appalling scenario, jobs have been structured around large governamental corporations. However, the South Africa government can no longer become the only main source of job creation. The emphasis should be shifted towards small and medium enterprises by moving from the idea of seeking employment to one to creating employment for oneself and others (GEM 2015).

New socio-economic conditions need to be proposed by developing strategies to positively influence business and academic research through policy makers at local and state levels Smilor et al. (1989), which has been visible in startups' geographically concentrated areas (Butler, 2010).

Studies have shown that well-developed regions have evolved an efficient institutional support for emerging entrepreneurial activities (Stephens, et al. 2019). It explains how macro features have been played a key role in those well-off regions (Gibson \& Butler 2013). al. Contrarily, South African regulation not only has severely hampered startups (Estrin \& Prevezer, 2010) but also has raised socio-economic conflicts which have been severely affecting the quality of the product and services (Ahlquist \& Prakash, 2010).

Moving from the macro factors influence to the domestic ecosystem's entrepreneurial activity, our results do not support the direct effect of the domestic ecosystem on emerging entrepreneurial activity $(\mathrm{H} 1: \mathrm{DE} \rightarrow$ EEA, $\beta=-$ $0.049, \mathrm{t}=0.548)$. Rather, the results suggest that the effect of the domestic ecosystem on entrepreneurial activity is mediated by the presence of entrepreneurial networks. Hence, domestic ecosystems are more likely to affect entrepreneurial networks, which then drive the effect on emerging entrepreneurial activity. This observation is a result of the rejection of $\mathrm{H} 1$ and the support of $\mathrm{H} 2(\mathrm{DE} \rightarrow \mathrm{NE}, \beta=0.695, \mathrm{t}=14.368)$ and $\mathrm{H} 3(\mathrm{NE} \rightarrow \mathrm{EEA}, \beta=0.152$, $\mathrm{t}=2.275$ ). Then, entrepreneurs engage in a domestic ecosystem their evolving networks (Perry-Smith, Mannucci 2017) in response to changing resource needs (Slotte-Kock, Coviello 2010). That network is based on developing relational strategies to gain others influence to maximise their own abilities and interests (Hassenteufel 2008). Their supporting elements interact in an environment which should foster the start-ups' growth (Mäkinen, Dedehayir 2012). However, mediation analysis revealed that the mediation effect (0.107) is not significant at 


\section{ENTREPRENEURSHIP AND SUSTAINABILITY ISSUES}

ISSN 2345-0282 (online) http://jssidoi.org/jesi/

2020 Volume 7 Number 4 (June)

http://doi.org/10.9770/jesi.2020.7.4(34)

$\mathrm{p}<0.05$, as the bias corrected confidence interval does include zero $(-0.005 ; 0.201)$. Nevertheless, the significant relationship between domestic ecosystems and entrepreneurial networks remains important and offers fertile ground for further investigation.

Then, efficient startups depend on effective nodes of collaborations and associated proceeds (Steier \& Greenwood, 2000). That collaboration represents a set of inter-depende actors or components to undertake new business through start-ups in a specific geographical area (Simsek 2003)

It is precisely a key factor in developing countries where social connection is a big asset in the take-off of a new business among entrepreneurs (Dahl \& Sorenson 2010), enabling them to use their existing previous contacts (Romanelli \& Feldman 2004). In other words, the main challenge for entrepreneurs does not lie in the novelty of a product or service but rather in the relevant social network which supports the new business (La Rocca \& Snehota 2014). Those social network ties decisively influence the personal decision to start a new tech business, especially among young people (White \& Green 2010). This is especially relevant in the domestic system in developing countries (Williams \& Hovorka, 2013).

Regarding the influence of entrepreneurship education on emerging entrepreneurial activities, the results support the positive relationship among those variables (H4: EE $\rightarrow$ EEA, $\beta=0.306, t=3.442)$. The relevance of entrepreneurship education toward entrepreneurial orientation is widely manifested in the literature review (Sullivan 2000). That orientation implies risk taking and proactive behaviour which decisively depend on the national culture (Kreiser et al. 2010). This challenge is even more needed in the South African economy as a tool to contribute to the creation of start-ups companies, especially among young people (Luiz, 2002).

That is precisely the main objective of the Youth Enterprise Development Strategy (2013-2023) implemented by the South African government. According to Herrington et al. (2014) South African private and public sectors have failed to absorb the growing number of job seekers. As a result, the South African Entrepreneurial Activity rate decreased from $9.1 \%$ in 2011 to $7.3 \%$ in 2012. South Africa's TEA is significantly below the average of efficiency-driven countries (14.3\%). Then, strategies need to be settled to increase the attention on entrepreneurship for contributing to economic growth and job creation.

Nevertheless, the lack of South African entrepreneurial skills (Von Broembsen et al. 2005:36) become one of the prime factors which is limiting its economic growth and the creation of emerging business activities. In other words, the level of young people who have dropped out from the education system has been increased in the last years. That factor enlarges the main problem which is the failure to provide relevant occupational skills to the future employees.

In addition, the results show that entrepreneurship education positively influences the emerging start-ups (H6: ER $\rightarrow$ EEA, $\beta=0.162, t=2.330$ ) through entrepreneurship research (H5: $E E \rightarrow E R, \beta=0.474, t=6.751)$. In other words, the path between entrepreneurship and emerging micro entrepreneurial activities is mediated by entrepreneurship research. In this case, mediation analysis revealed a significant $(\mathrm{p}<0.05)$ interaction effect $(0.077)$ with zero not included in the bias corrected confidence interval $(0.019 ; 0.159)$. This notion is supported in the current study by the rejection of the null hypothesis in favour of the alternative hypothesis that argues for the impact of entrepreneurship education on entrepreneurship research. It explains that data research not only assists entrepreneurs to improve their entrepreneurial activity and find answers to many unexplored questions (Aparicio et al. 2019) but also can be used to gain insights into social networks and understanding the underlying trends in order to efficiently develop their emerging activities (Pentland 2014). 


\section{ENTREPRENEURSHIP AND SUSTAINABILITY ISSUES}

ISSN 2345-0282 (online) http://jssidoi.org/jesi/

2020 Volume 7 Number 4 (June)

http://doi.org/10.9770/jesi.2020.7.4(34)

This positive effect of entrepreneurship research on emerging micro entrepreneurial activity is visible in cities with a high level of investment in innovation and technology. These cities end up with a considerable the level of patent activity that affects their productivity (Rothwell et al. 2013).

\section{Conclusions}

The conclusions are organized in two sections. First is the impact of general macro entrepreneurial factors in South African emerging entrepreneurial activities. Second is the role that the domestic ecosystem and network plays in that new business. Third is the key aspect of education and research in entrepreneurship in improving the start-ups efficiency in emerging economies.

First: Emerging activities are spawned, developed, and grow within a larger context of socio-economic conditions. Much too often, policymakers that attempt to enhance entrepreneurial activity are confronted with a paradox situation where the key to economic development is linked to the creation of start-ups firms, and yet the economic conditions within which the start-ups need to be created are not conducive for emerging entrepreneurial activities.

From that view, macro reforms are needed to reverse the weak South African business environment, particularly for small and medium-sized enterprises (GEM 2017, 6), and to turn political, social, and economic factors into a favourable environment (Timmons 1994) for developing entrepreneurial attitudes (Bateman 1997) among South African entrepreneurs.

Studies have shown that the surveillance of corruption is highly and positive aligned with individual trust in entrepreneurial activities and innovation (Anokhin \& Schulze 2009). Similarly, according to Bowen and De Clerq (2008) entrepreneurial resources allocated in financing and education decisively reduce the level of corruption.

Second: In South Africa, a favourable domestic ecosystem based on government policy and market entry regulations, such as reduction of transaction costs and economies of scale (Krugman\& Obstfeld, 1997), should be addressed to improve entrepreneurial networks. As a crucial entrepreneurial feature, networking (Reynolds 1997) not only explains the entrepreneur's failure or success (Honin et al. 2005) but also is the bridge to link the organizational and social features in emerging business (La Rocca et al. 2016) between individuals, companies, and society (Westhead \& Wright, 2011).

Third: An entrepreneurship agenda has become a targeted tool for universities, government, and international institutions in order to reduce the African high rate of unemployment (UN 2013). However, the challenge of efficiently raising the occupation level in South Africa remains partially unanswered. Several methodologies have recently come out in technological countries through problem-based learning (Greenberg et al. 2011), the knowledge acquisition model (Ratten 2017), etc. It is crucial to develop critical thinking based on creative logic and knowledge-transformation in young and new entrepreneurs as relevant skills for living life (Leong 2013).

Fouth: Based on the high significance of the model (adjusted $\mathrm{R}^{2}=0.748$ ) (Hair et al. 2019) the model shows a combined effect of domestic ecosystems (DE), entrepreneurial networks (EN), entrepreneurship education (EE), and research in entrepreneurship (ER) on the emerging entrepreneurial activities (EEA). According to the results, recommendations to decision-makers can be drawn to better understand the causal relationships between macro and micro factors on startup activity in South Africa

Some limitations of the study have to be arisen. The results of the study are context-specific and based on a limited sample. Furthermore, we have selected a rather narrow set of macro indicators and therefore no parsimony 


\section{ENTREPRENEURSHIP AND SUSTAINABILITY ISSUES}

ISSN 2345-0282 (online) http://jssidoi.org/jesi/

2020 Volume 7 Number 4 (June)

http://doi.org/10.9770/jesi.2020.7.4(34)

is claimed. To this end we recommend that future studies can identify more accurate indicators by using the procedure suggested by Saura et al. (2019) employing a Latent Dirichlet Allocation (LDA) model to analyse user generated content (UGC). However, the results show that emerging markets, in particular, have to consider economic and political initiatives that promote the growth of micro-level entrepreneurial activity. Such an approach will result in more startups and ultimately stimulate economic development.

The current study shows that by nurturing entrepreneurship education and research, while also seeking to develop domestic ecosystems and growing entrepreneurial network capabilities, such a feat might just be possible. The challenge to create more start-ups companies remains paradoxical, and therefore policy instruments need to aim both at creating favourable economic conditions for startups to emerge and at the same time supporting individual start-up businesses. Thus, the solution is to be found in both influencing the environment and individual behaviour.

\section{References}

Acemoglu, D. (2008). Oligarchic and democratic societies. Journal of the European Economic Association, 6(1), pp. 1-44. https://doi=10.1.1.687.1163\&rep=rep1\&type=pdf

Acs, Z. J., Stam, E., Audretsch, D. B., \& O'Connor, A. (2017). The lineages of the entrepreneurial ecosystem approach. Small Business Economics, 49(1), pp. 1-10. https://doi.org/10.1007/s11187-017-9864-8

Agrawal, A., Gans, J., \& Goldfarb, A. (2016). The simple economics of machine intelligence. Harvard Business Review, 17(1), pp. $2-5$. Retrieved from https://hbr.org/2016/11/the-simple-economics-of-machine-intelligence

Ahlquist, S., \& Prakash, A. (2010). FDI and the costs of contract enforcement in developing countries. Policy Sciences, 43(2), pp. 181-200. https://doi: 10.1007/s11077-009-9093-3

Anokhin, S., \& Schulze, W.S. (2009). Entrepreneurship, innovation, and corruption. Journal of Business Venturing, 24(5), pp. 465-476. https://doi.org/10.1016/j.jbusvent.2008.06.001

Aparicio, G., Iturralde, T., \& Maseda, A. (2019). Conceptual structure and perspectives on entrepreneurship education research: A bibliometric review. European Research on Management and Business Economics. (no volume), https://doi.org/10.1016/j.iedeen.2019.04.003

Bagozzi, R.P., \& Yi, Y. (1988). On the evaluation of structural equation models. Journal of the academy of marketing science, 16(1), pp. 74-94. Retrieved from https://link.springer.com/content/pdf/10.1007/BF02723327.pdf

Bateman, M. (1997). Business cultures in Central and Easter Europe. Oxford: Butterworth-Heinemann.

Baumol, W. (1993). Entrepreneurship, management and the structure of payoffs, Cambridge, MA: MIT Press.

Becherer, R.C., \& Maurer, J.G. (1999). The proactive personality disposition and entrepreneurial behavior among small company presidents. Journal of small business management, 37(1), p.28. Retrieved from https://search.proquest.com/docview/220955939/fulltextPDF/61B715C2C549449APQ/1?accountid=17204

Béland, D. (2005). Ideas and social policy: An institutionalist perspective. Social Policy \& Administration, 39(1), pp. 1-18. https://doi.org/10.1111/j.1467-9515.2005.00421.x

Bosma, N., Schutjens, V.A.J.M., \& Stam, E. (2009). Determinants of early-stage entrepreneurial activity in European regions, Distinguishing low and high ambition entrepreneurship. Making the difference in local, regional and national economies: Frontiers in European entrepreneurship research, pp. 49-80. https://doi.org/10.1007/s00168-010-0375-7

Bowen, H.P., \& De Clercq, D. (2008). Institutional context and the allocation of entrepreneurial effort. Journal of International Business Studies, 39(4), pp.747-767. https://doi.org/10.1057/palgnave.jibs.8400343

Butler, J.S. (2010). The University of Texas at Austin. In: Fetters, M., Greene, P., Rice, M., Butler, J. (Eds.), The Development of University-Based Entrepreneurship Ecosystems. Edward Elgar Publishing. 


\section{ENTREPRENEURSHIP AND SUSTAINABILITY ISSUES}

ISSN 2345-0282 (online) http://jssidoi.org/jesi/

2020 Volume 7 Number 4 (June)

http://doi.org/10.9770/jesi.2020.7.4(34)

Chin, W.W., Marcolm, B., \& Newsted, P. (2003). A partial least square latent variable modeling approach for measuring interaction effects: Results from a Monte Carlo simulation study and an electronic-mail emotion/adoption study. Information Systems Research, 14:2, pp. 189-217.

Cohen, B. (2006). Sustainable valley entrepreneurial ecosystems, Bus. Strategy Environ. 15(1) 1-14. https://doi.org/10.1002/bse.428

Crush, J., \& Peberdy, S. (2018). Criminal tendencies: Immigrants and illegality in South Africa. Series Editors: Jonathan Crush and Vincent Williams. Southern African Migration Project.

Dahl, M.S., \& Sorenson, O. (2010). The social attachment to place. Social Forces, 89(2), pp.633-658. https://doi.org/10.1.1.1025.3352\&rep=rep1\&type=pdf

Damro, C. (2012). Market power Europe. Journal of European Public Policy, 19(5), pp. 682-699. https://doi.org/10.1080/13501763.2011.646779

Debortoli, S., Müller, O., \& vom Brocke, J. (2014). Comparing business intelligence and big data skills. Business \& Information Systems Engineering, 6(5), pp.289-300. https://doi.org/10.1007/s11576-014-0432-4

Department of Trade and Industry (DTI), (2013). Youth Enterprise Development Strategy 2013-2023. Retrieved from http://www.dti.gov.za

Du Toit, A., (2004). 'Social exclusion'discourse and chronic poverty: a South African case study. Development and Change, 35(5), pp. 987-1010. https://doi.org/10.1111/j.1467-7660.2004.00389.x

Duchesneau, D. A., \& Gartne R.W.B. (1990). A profile of new venture success and failure in an emerging industry. Journal of business venturing, vol. 5, no 5, p. 297-312. https://doi.org/10.1016/0883-9026(90)90007-G

Estrin, S., Korosteleva, J., \& Mickiewicz, T., (2013). Which institutions encourage entrepreneurial growth aspirations?. Journal of business venturing, 28(4), pp.564-580. https://doi.org/10.1016/j.jbusvent.2012.05.001

Estrin, S., \& Prevezer, M., (2010). A survey on institutions and new firm entry: How and why do entry rates differ in emerging markets?. Economic systems, 34(3), pp.289-308. https://doi.org/10.1016/j.ecosys.2010.01.003

Fernández, A., \& Gulan, A., (2015): Interest rates, leverage, and business cycles in emerging economies: the role of financial frictions. Am. Econ. J.-Macroecon. (3), 153-188. https://doi.org/10.1257/mac.20120141

Fornell, C., \& Larcker. D.F. (1981). Evaluating structural equation models with unobservable variables and measurement errors. Journal of Marketing Research, 18, 39-50. https://doi.org/10.1177/002224378101800104

Freiling, J., \& Baron, T. (2017). A resource-based view of entrepreneurial ecosystems. In Technologie, Strategie und Organisation (pp. 6584). Springer Gabler, Wiesbaden.

Frese, M. (ed.). (1998). Erfolgreiche Unternehmensgründer: Psychologische Analysen und praktische Anleitungen für Unternehmer in Ostund Westdeutschland. Göttingen: Hogrefe. GEM 2016/2017 Global Report - GEM Global Entrepreneurship Monitor. Retrieve from https://www.gemconsortium.org/report/49812

George, G.M., Haas, R., \& Pentland, A. (2014). Big data and management: From the editors. Academy of Management Journal, 57(2), pp. 321-326. https://doi.org/https://doi.org/10.5465/amj.2014.4002

Gibson, D.V., \& Butler, J.S. (2013). Sustaining the technopolis: The case of Austin, Texas. World Technopolis Review, 2(2-6), pp.64-80. http://dx.doi.org/10.7165/wtr2013.2.2.64

Gouws, E. (2002). Entrepreneurship education: implications for teacher training. South African Journal of Higher Education, 16(2), pp. 4148. http://dx.doi.org/10.4314/sajhe.v16i2.25241

Greenberg, D., McKone-Sweet, K., \& Wilson, H.J. (2011). The new entrepreneurial leader: Developing leaders who shape social and economic opportunity. Berrett-Koehler Publishers.

Hair, J. F., Risher, J. J., Sarstedt, M., \& Ringle, C.M. (2019). When to use and how to report the results of PLS-SEM. European Business Review, 31(1), 2-24. https://doi.org/10.1108/EBR-11-2018-0203

Hair, J.F., Hult, T.M., Ringle, Ch. M., \& Sarstedt, M. (2017). A primer on partial least squares structural equation modeling (PLS-SEM). 2nd ed. Los Angeles: Sage.

Hair, JF., Ringle, C., \& Sarstedt, M. (2011). PLS-SEM: Indeed a silver bullet. Journal of Marketing theory and Practice, vol. 19, no 2, p. 139-152. https://doi.org/10.2753/MTP1069-6679190202

Henrekson, M., \& Sanandaji, T. (2014). Small business activity does not measure entrepreneurship. Proceedings of the National Academy of Sciences, 111(5), pp. 1760-1765. https://doi.org/10.1073/pnas.1307204111 


\section{ENTREPRENEURSHIP AND SUSTAINABILITY ISSUES}

ISSN 2345-0282 (online) http://jssidoi.org/jesi/

2020 Volume 7 Number 4 (June)

http://doi.org/10.9770/jesi.2020.7.4(34)

Henseler, J., Ringle, C.M., \& Sarstedt, M. (2015). A new criterion for assessing discriminant validity in variance-based structural equation modeling. Journal of the academy of marketing science, 43(1), pp.115-135. https://doi.org/10.1007/s11747-014-0403-8

Herrington, M., Kew, J., \& Kew, P. (2014). GEM South Africa 2013 Report. http://www.gemconsortium.org/docs/3336/gem-south-africa2013-reportaccessed 11(09).

Ho, S.Y. (2019). Macroeconomic determinants of stock market development in South Africa. International Journal of Emerging Markets, 14(2), pp. 322-342. https://doi.org/10.1108/IJoEM-09-2017-0341

Honig, B., Davidsson, P., \& Karlsson, T. (2005). Learning strategies of nascent entrepreneurs. Journal of Competence-based Management, 1(3), pp.67-88. Retrieved from https://www.effectuation.org/sites/default/files/research papers/learning-strategies-nascent.pdf

Ikebuaku, K., \& Dinbabo, M. (2018). Beyond entrepreneurship education: business incubation and entrepreneurial capabilities. Journal of Entrepreneurship in Emerging Economies, 10(1), pp.154-174. https://doi.org/10.1108/JEEE-03-2017-0022

Isaacs, E., Visser, K., Friedrich, C., \& Brijlal, P. (2007). Entrepreneurship education and training at the Further Education and Training (FET) level in South Africa. South African Journal of Education, 27(4), pp. 613-630.

Isenberg, D.J. (2010). How to start an entrepreneurial revolution. Harvard business review, 88(6), pp. 40-50. Retrieved from https://institute.coop/sites/default/files/resources/Isenberg\%20-\%20How\%20to\%20Start\%20an\%20Entrepreneurial\%20Revolution.pdf

Jones, D., \& Baumgartner, F. (2005). The politics of attention: How government prioritizes problems. Chicago: University of Chicago Press.

Kennedy, M.T. (2008). Getting counted: Markets, media, and reality. American sociological review, 73(2), pp.270-295. https://doi.org/10.1177/000312240807300205

Klasing, M.J. (2013). Cultural dimensions, collective values and their importance for institutions. Journal of Comparative Economics, 41(2), pp.447-467. https://doi.org/10.1016/j.jce.2012.09.003

Kline, R.B. (2011). Principles and practice of structural equation modeling. New York: Guilford Press.

Klueter, T., \& Rosenkopf, L. (2013). Opening Up but Staying Local: Insights from Partnership Formations between Established and Startup Firms. Retrieved from SSRN 2186034.

Kock, N. (2015). Common method bias in PLS-SEM: A full collinearity assessment approach. International Journal of e-Collaboration (IJeC), 11(4), pp. 1-10. https://doi.org/10.4018/ijec.2015100101

Kose, M.A., (2002). Explaining business cycles in small open economies: how much do world prices matter? J. Int. Econ., 56(2). Elsevier, pp.299-327. https://doi.org/10.1016/S0022-1996(01)00120-9

Kreiser, P.M., Marino, L.D., Dickson, P., \& Weaver, K.M. (2010). Cultural influences on entrepreneurial orientation: The impact of national culture on risk taking and proactiveness in SMEs. Entrepreneurship theory and practice, 34(5), pp. 959-984. https://doi.org/10.1111/j.1540-6520.2010.00396.X

Krugman, P.R., \& Obstfeld, M. (1997). International Economics: Theory and Policy, 4th ed. Addison-Wesley, Reading, Mass.

La Porta, R., Lopez-de-Silanes, F., \& Shleifer, A. (2008). The economic consequences of legal origins. Journal of economic literature, 46(2), pp.285-332. https://doi.org/10.1257/jel.46.2.285

La Rocca, A., Hoholm, T., \& Mørk, B.E. (2017). Practice theory and the study of interaction in business relationships: Some methodological implications. Industrial Marketing Management, 60, pp.187-195. https://doi.org/10.1016/j.indmarman.2016.04.002

Leong, P.A. (2013). Thinking critically: a look at students' critiques of a research article. Higher Education Research \& Development, 32(4), pp.575-589. https://doi.org/10.1080/07294360.2012.708322

Lepoutre, J., Justo, R., Terjesen, S., \& Bosma, N. (2013). Designing a global standardized methodology for measuring social entrepreneurship activity: The Global Entrepreneurship Monitor social entrepreneurship study. Small Business Economics, 40(3), pp.693714. https://doi.org/10.1007/s11187-011-9398-4

Li, T.M. (2017). After development: surplus population and the politics of entitlement. Development and Change, 48(6), pp.1247-1261.

Luiz, J. (2002). Small business development, entrepreneurship and expanding the business sector in a developing economy: The case of South Africa. Journal of Applied Business Research, 18(2), pp.53-68. https://doi.org/10.19030/jabr.v18i2.2115

Mäkinen, S.J., \& Dedehayir, O. (2012). Business ecosystem evolution and strategic con-siderations: A literature review, Proceedings of the Eighteenth International ICEConference on Engineering, Technology and Innovation (ICE), IEEE, pp.1-10.

https://doi.org/10.1109/ICE.2012.6297653 


\section{ENTREPRENEURSHIP AND SUSTAINABILITY ISSUES}

ISSN 2345-0282 (online) http://jssidoi.org/jesi/

2020 Volume 7 Number 4 (June)

http://doi.org/10.9770/jesi.2020.7.4(34)

Malhotra, N. (2019). Marketing research: An applied orientation. 7th Edition. Pearson Education.

Maune, A. (2017). Developing competitive advantage through startups and venture capital in emerging markets: A view from Israel. institutions, 7(3), p. 85-115. https://doi.org/10.22495/rgcv7i3p9

Mbalula, F.A. (2017). Addendum to the SAP annual report 2016/2017 (South African Police Service Crime Statistics 2016/2017 No. 226/2017) (pp. 1-131). Pretoria: South African Police Service.

McKinsey Global Institute, (2011). Big data: The next frontier for innovation, competition, and productivity. McKinsey \& Company. New York.

Meseguer, C. (2005). Policy learning, policy diffusion, and the making of a new order. The Annals of the American Academy of Political and Social Science, 598(1), pp.67-82. https://doi.org/10.1177/0002716204272372

Mlambo-Ngcuka, P. (2006). Address delivered by the Deputy President, Phumzile Mlambo-Ngcuka, at the launch of the Joint Initiative for Priority Skills Acquisition, 27 March. Retrieved from http://www.info.gov.za/speeches

Moodley, S. (2003). The challenge of e-business for the South African apparel sector. Technovation, 23(7), pp.557-570.

https://doi.org/10.1016/S0166-4972(02)00002-0

Morris, M. H., Allen, J. A., Kuratko, D. F., \& Brannon, D. (2010). Experiencing family business creation: Differences between founders, nonfamily managers, and founders of nonfamily firms. Entrepreneurship: Theory and Practice, 34(6), 1057. Gale Academic Onefile. DOI: https://doi.org/10.1111/j.1540-6520.2010.00413.x

Munemo, J. (2012). Entrepreneurship in developing countries: is Africa different? Journal of Developmental Entrepreneurship, 17(01), p.1250004. https://doi.org/10.1142/S1084946712500045

Murdock, K.A., \& Varnes, C.J. (2018). Beyond effectuation: Analysing the transformation of business ideas into ventures using actornetwork theory. International Journal of Entrepreneurial Behavior \& Research, 24(1), pp. 256-272. https://doi.org/10.1108/IJEBR-01-2017$\underline{0039}$

Naik, PK. \& Padhi, P. (2012). The Impact of Macroeconomic Fundamentals on Stock Prices Revisited: Evidence from Indian Data. Eurasian Journal of Business and Economics, 5(10), 25-44.

North, D. (1990). Institutions, institutional change and economic performance. Cambridge: Cambridge University Press.

OECD, (2014). African Economic Outlook 2014, www.africaeconomicoutlook.org

Olawale, F., \& Garwe, D. (2010). Obstacles to the growth of new SMEs in South Africa: A principal component analysis approach. African Journal of Business management, 4(5), pp. 729-738. Retrieved from http://citeseerx.ist.psu.edu/viewdoc/download?doi=10.1.1.845.4589\&rep=rep1\&type=pdf

Patel, L. (2015). Social welfare \& social development in South Africa (2nd ed.). Cape Town: Oxford University Press.

Pentland, A. (2014). Social physics. New York: Penguin.

Perry-Smith, J. E., \& Mannucci, P.V. (2017). From creativity to innovation: The social network drivers of the four phases of the idea journey. Academy of Management Review, 42: 53- 79. https://doi.org/10.5465/amr.2014.0462

Quinones, Gerardo, N.B, \& Heeks, R. (2015). A literature review of E-entrepreneurship in emerging economies: Positioning research on Latin American digital startups. Entrepreneurship in BRICS. Springer, Cham, pp. 179-208.

Ratten, V. (2017). Entrepreneurial universities: the role of communities, people and places. Journal of Enterprising Communities: People and Places in the Global Economy, 11(03), pp.310-315. https://doi.org/10.1108/JEC-03-2017-0021

Rauch, A., \& Frese, M., (2000). Psychological approaches to entrepreneurial success: A general model and an overview of findings. International review of industrial and organizational psychology, 15, pp.101-142.

Reynolds, P. (1997). Who starts firms? Preliminary explorations of firms in gestation. Small Business Economics, 9, 449-462. Retrieved from https://link.springer.com/content/pdf/10.1023/A:1007935726528.pdf

Ringle, C.M., Wende, S., Becker, J.M. (2015). SmartPLS 3. Bönningstedt: SmartPLS. Retrieved from http://www.smartpls.com

Robina-Ramrez, R., Fernández-Portillo A., Carlos Díaz-Casero, J. 2019. Green start-ups' attitudes towards nature when complying with the corporate law. Complexity. https://doi.org/10.1155/2019/4164853

Rodgers, S., Sbizzera, I., Cockayne, S., Fairhurst, C., Lamb, S.E., Vernon, W., \& Torgerson, D. (2018). A nested randomised controlled trial of a newsletter and Post-it® note did not increase postal questionnaire response rates in a falls prevention trial. F1000 Research, 7 , 1083. https://doi.org/10.12688/f1000research.14591.1 


\section{ENTREPRENEURSHIP AND SUSTAINABILITY ISSUES}

ISSN 2345-0282 (online) http://jssidoi.org/jesi/

2020 Volume 7 Number 4 (June)

http://doi.org/10.9770/jesi.2020.7.4(34)

Rogerson, C.M. (2018). Towards pro-poor local economic development: The case for sectoral targeting in South Africa. In: Local economic development in the changing world (pp. 75-100). London: Routledge.

Romanelli, E., Feldman, M., (2004). Anatomy of cluster development: emergence and convergence in the US human biotherapeutics, 1976-2003. In: Braunersfjeld, P., Feldman, M.P. (Eds.) The Genesis of Clusters: Technology-Based Industrial Development. Oxford University Press, New York.

Rothwell, J., Lobo, J., Strumsky, D., \& Muro, M. (2013). Patenting prosperity: invention and economic performance in the United States and its metropolitan areas. Metropolitan Policy Program at Brookings 1-49.

Roundy, P.T., (2017). "Small town” entrepreneurial ecosystems: Implications for developed and emerging economies. Journal of Entrepreneurship in Emerging Economies, 9(3), pp.238-262. https://doi.org/10.1108/JEEE-09-2016-0040

Sánchez, C.M., \& Lehnert, K., (2018). Firm-level trust in emerging markets: the moderating effect on the institutional strength-corruption relationship in Mexico and Peru. Estudios Gerenciales, 34 (147), pp. 127-138. http://dx.doi.org/10.18046/j.estger.2018.147.2656

Sarstedt, M., Hair, J.F., Ringle, C.M., Thiele, K.O., \& Gudergan, S.P., (2016). Estimation issues with PLS and CBSEM: Where the bias lies! Journal of Business Research, 69(10), pp.3998-4010. https://doi.org/10.1016/j.jbusres.2016.06.007

Saura, J. R., Palos-Sanchez, P., \& Grilo, A. (2019). Detecting Indicators for Startup Business Success: Sentiment Analysis Using Text Data Mining. Sustainability, 11(3), 917. https://doi.org/10.3390/su11030917

Schwab, K. 2018. The global competitiveness report (2018): Full data edition. En World Economic Forum. Retrieved from http://www3.weforum.org/docs/GCR2018/05FullReport/TheGlobalCompetitivenessReport2018.pdf

Scott, W., \& Meyer, J. (1984). Organisational environments: Ritual and rationality. Beverly Hills, CA: Sage Publications.

Shane, S., \& Venkataraman, S. (2000). The promise of entrepreneurship as a field of research. Academy of management review, 25(1), pp.217-226. https://doi.org/10.5465/amr.2000.2791611

Simsek, Z.M.H. \& Lubatkin, S.W.F. (2003). Inter-firm networks and entrepreneurial behavior: A structural embeddedness perspective. Journal of Management, 29: 427-442. https://doi.org/10.1016/S0149-2063_03_00018-7

Slotte-Kock, S., \& Coviello, N. (2010). Entrepreneurship research on network processes: A review and ways forward. Entrepreneurship Theory and Practice, 34: 31- 57. https://doi.org/10.1111/j.1540-6520.2009.00311.x

Smilor, R.W., Gibson, D.V., \& Kozmetsky, G. (1989). Creating the technopolis: high-technology development in Austin, Texas. Journal of Business Venturing, 4(1), pp. 49-67. https://doi.org/10.1016/0883-9026(89)90033-5

Smith, N.R., \& Miner, J.B. (1983). Type of entrepreneur, type of firm, and managerial motivation: Implications for organizational life cycle theory. Strategic management journal, 4(4), pp.325-340. https://doi.org/10.1002/smj.4250040404

Stam, E. (2014). The Dutch entrepreneurial ecosystem. SSRN 2473475. Retrieved from http://ssrn.com/abstract=2473475

Stam, E. (2015). Entrepreneurial ecosystems and regional policy: a sympathetic critique. European Planning Studies, 23(9), pp. 1759-1769. https://doi.org/10.1080/09654313.2015.1061484

Stam, E., Bosma, N., Van Witteloostuijn, A., de Jong, J., Bogaert, S., Edwards, N., \& Jaspers, F. (2012). Ambitious entrepreneurship. A review of the academic literature and new directions for public policy. Den Haag: Adviesraad voor Wetenschap en Technologie-beleid (AWT).

Stats SA. (2017a). Quarterly labour force survey. Quarter 3, 2017. Pretoria: Statistics South Africa.

Stats SA. (2017b). Poverty trends in South Africa: An examination of absolute poverty between 2006 and 2015. Pretoria: Statistics South Africa.

Steier, L., \& Greenwood, R. (2000). Entrepreneurship and the evolution of angel financial networks. Organization Studies, 21(1), pp. 163192. https://doi.org/10.1177/0170840600211002

Stephens, B., Butler, J.S., Garg, R., \& Gibson, D.V. (2019). Austin, Boston, Silicon Valley, and New York: Case studies in the location choices of entrepreneurs in maintaining the Technopolis. Technological Forecasting and Social Change, 146, pp. $267-280$.

https://doi.org/10.1016/j.techfore.2019.05.030

Sullivan, R. (2000). Entrepreneurial learning and mentoring. International Journal of Entrepreneurial Behavior \& Research, 6 (3), pp. 160175. https://doi.org/10.1108/13552550010346587

Teo, T.S., Srivastava, S.C., Jiang, L. (2008). Trust and electronic government success: An empirical study. Journal of management information systems, 25(3), pp.99-132. https://doi.org/10.2753/MIS0742-1222250303 


\section{ENTREPRENEURSHIP AND SUSTAINABILITY ISSUES}

ISSN 2345-0282 (online) http://jssidoi.org/jesi/

2020 Volume 7 Number 4 (June)

http://doi.org/10.9770/jesi.2020.7.4(34)

Tesfayohannes, M. (2012). African entrepreneurs should plan and aspire beyond the fence at the current complex global business environment. Sigmund Weis School of Business, Susquehanna University, Selinsgrove, PA, USA.

Timmons, J. (1994). New venture creation. Boston, MA: Irwin.

Timmons, J.A., Smollen, L.E., \& Dingee, A.L.M. (1985). New venture creation: A guide to entrepreneurship. Hamate, Ill: Irwin.

Trading Economics, 2018. South Africa GDP Annual Growth Rate 1994-2018. Retrieved from: 12.03.2018

https://tradingeconomics.com/south-africa/gdp-growthannual

United Nations Africa Renewal, 2013. Africa's youth: A "ticking time bomb" or an opportunity? UN department of public information. Retrieved from https://www.un.org/africarenewal/magazine/may-2013/africa\%E2\%80\%99s-youth-\%E2\%80\%9Cticking-timebomb\%E2\%80\%9D-or-opportunity

Uprichard, E. (2013). Sampling: Bridging probability and non-probability designs. International Journal of Social Research Methodology, 16(1), 1-11. https://doi.org/10.1080/13645579.2011.633391

Upstart Business Strategies, (2006). Integrated strategy on the promotion of entrepreneurship and small business. Pretoria: Department of Trade and Industry.

Urban, B., \& Hwindingwi, R. (2016). The influence of institutional factors on MNC's triple bottom-line reporting: A focus on African emerging markets (AEMs). International Journal of Emerging Markets, 11(4), 497-513. ISSN: 1746-8809

Van Gelderen, M., Thurik, R., Bosma, N., (2005). Success and risk factors in the pre-startup phase. Small business economics, 24(4), pp.365-380. https://doi.org/10.1007/s11187-004-6994-6

Van Niekerk, R. (2013). Social policy, social citizenship and the historical idea of a social democratic welfare state in South Africa. Transformation: Critical Perspectives on Southern Africa, 81(1), pp.115-143. https://doi.org/10.1353/trn.2013.0010

Venkataraman, S. (2019). The distinctive domain of entrepreneurship research. In Seminal Ideas for the Next Twenty-Five Years of Advances (pp. 5-20). Emerald Publishing Limited. https://doi.org/10.1108/S1074-754020190000021009

Von Broembsen, M., Wood, E., \& Herrington, M. (2005). Global Entrepreneurship Monitor, South African Report. Retrieved from http://www.gbs.nct.ac.za/gbswebb/userfiles/gemsouthafrica2000pdf

Walker, M., \& Mkwananzi, F. (2015). Challenges in accessing higher education: A case study of marginalised young people in one South African informal settlement. International Journal of Educational Development, 40, pp. 40-49. https://doi.org/10.1016/j.ijedudev.2014.11.010

Waller, M.A., \& Fawcett, S.E. (2013). Click here for a data scientist: Big data, predictive analytics, and theory development in the era of a maker movement supply chain. Journal of Business Logistics, 34(4), pp.249-252. https://doi.org/10.1111/jbl.12024

Watson, K., Hogarth-Scott, S., \& Wilson, N. (1998). Small business start-ups: success factors and support implications. International Journal of Entrepreneurial Behavior \& Research, 4(3), pp.217-238. https://doi.org/10.1108/13552559810235510

Webster, E. (2013). The promise and the possibility: South Africa's contested industrial relations path. Transformation: Critical Perspectives on Southern Africa, 81(1), pp.208-235. https://doi.org/ $\underline{10.1353 / \operatorname{trn} .2013 .0000}$

Weiblen, T., \& Chesbrough, H.W. (2015). Engaging with startups to enhance corporate innovation. California Management Review, 57(2), pp.66-90. https://doi.org/10.1525/cmr.2015.57.2.66

Westhead, P., \& Wright, M. (2011). David Storey's optimism and chance perspective: A case of the Emperor's new clothes? International Small Business Journal, 29(6), pp.714-729. https://doi.org/10.1177/0266242611424552

White, R.J., \& Green, A.E., (2011). Opening up or Closing down Opportunities? The role of social networks and attachment to place in informing young peoples' attitudes and access to training and employment. Urban Studies, 48(1), pp.41-60. https://doi.org/10.1177/0042098009360234

Williams, M., \& Hovorka, A.J. (2013). Contextualizing youth entrepreneurship: The case of Botswana's young farmers fund. Journal of Developmental Entrepreneurship, 18(04), p.1350022. https://doi.org/10.1142/S1084946713500222

Winkler, H., \& Simões, A.F., La Rovere, E.L., Alam, M., Rahman, A., \& Mwakasonda, S. (2011). Access and affordability of electricity in developing countries. World development, 39(6), pp.1037-1050. https://doi.org/10.1016/j.worlddev.2010.02.021

Wong, P.K., Ho, Y.P., \& Autio, E. (2005). Entrepreneurship, innovation and economic growth: Evidence from GEM data. Small business economics, 24(3), pp. 335-350. https://doi.org/10.1007/s1 1187-005-2000-1

Wongswan, J., (2006). Transmission of information across international equity markets. Rev. Financ. Stud. 19 (4), $1157-1189$. 


\section{ENTREPRENEURSHIP AND SUSTAINABILITY ISSUES}

ISSN 2345-0282 (online) http://jssidoi.org/jesi/

2020 Volume 7 Number 4 (June)

http://doi.org/10.9770/jesi.2020.7.4(34)

World Economic Forum, (2013). Entrepreneurial ecosystems around the globe and company growth dynamics. Davos: World Economic Forum. Retrieved from http://www3.weforum.org/docs/WEF EntrepreneurialEcosystems Report 2013.pdf

Zengyu Huang, V., Nandialath, A., Kassim Alsayaghi, A., \& Esra Karadeniz, E. (2013). Socio-demographic factors and network configuration among MENA entrepreneurs. International Journal of Emerging Markets, 8(3), pp. 258-281. https://doi.org/10.1108/17468801311330329

Zhao, Y.L., Song, M., \& Storm, G.L. (2013). Founding team capabilities and new venture performance: The mediating role of strategic positional advantages. Entrepreneurship: Theory and Practice, 37(4), 789+. Gale Academic Onefile. https://doi.org/10.1111/j.15406520.2012.00513.x

\section{Acknowledgements}

We want to expressly mention all the startups that effectively have collaborated in the research.

Rafael ROBINA-RAMÍREZ is an Assistant Professor of Business Administration in the Department of Business Management and Sociology at University of Extremadura (Spain). He has been the chief of the Entrepreneurship Department at the city of Cáceres (Spain) from 2002 to 2012. He is currently leading an initiative to promote entrepreneurs at the University of Extremadura. Research interests: entrepreneurship and environmental ethics, personal grow and development; sustainability and entrepreneurship.

ORCID ID: https://orcid.org/0000-0002-7117-8645

Gert HUMAN is a Professor of Strategy, Innovation and Entrepreneurship in the Department of Business Management at Stellenbosch University (South Africa). He chairs the unit for Entrepreneurship and Innovation in the department and is a member of the SMS, AMS, EMA, IMP and the South African Institute of Management Scientists. His work in complex business networks, business-to-business relationships and entrepreneurship has appeared in leading journals.

ORCID ID: https://orcid.org/0000-0002-3084-5042

Register for an ORCID ID:

https://orcid.org/register

Copyright (C) 2020 by author(s) and VsI Entrepreneurship and Sustainability Center

This work is licensed under the Creative Commons Attribution International License (CC BY).

http://creativecommons.org/licenses/by/4.0/

cC) (†) Open Access 